\title{
Effect of different surface modifications on the bonding of a soft liner to a denture base material ${ }^{*}$
}

\author{
Canan Akay(0000-0003-2781-8710) ${ }^{\alpha}$, Emre Mumcu(0000-0002-3791-6472) ${ }^{\alpha}$, Gülbahar Erdinç(0000-0002-0883-9834) ${ }^{\alpha}$
}

Selcuk Dent J, 2020; 7: 27-33 (Doi: 10.15311/selcukdentj.461557)

Başvuru Tarihi: 19 Eylül 2018 Yayına Kabul Tarihi: 13 Mart 2019

\section{ABSTRACT \\ Effect of different surface modifications on the bonding of a soft liner to a denture base material}

Background: The purpose of the study was to investigate the tensile bond strength of polydimethylsiloxane denture liner to denture base which was sandblasted with different size of aluminum oxide particles.

Methods: Forty rectangular heat-polymerized acrylic resin samples were processed for bond strength test. Samples were divided into 4 test groups $(n=10)$ according to the surface treatment as follows: Group I: no surface treatment, Group II: sandblasted and coated with tribochemical silica, Group III: sandblasted with $50 \mu \mathrm{m}$ aluminum oxide $\left(\mathrm{Al}_{2} \mathrm{O}_{3}\right)$ particles, Group IV: sandblasted with $110 \mu \mathrm{m} \mathrm{Al}_{2} \mathrm{O}_{3}$ particles. All samples were subjected to 5000 cycles of thermal cycling after connection with soft liner. The bond strength was determined by the tensile strength test using a universal testing machine. The normality of the data was tested by Shapiro-wilk test. Al data were analyzed using one-way ANOVA, and their mean values were compared using Tukey's HSD test $(p<0.05)$.

Result: The highest bond strength value was observed in Group II (1.51 $\pm 0.41 \mathrm{MPa})$. The lowest value was observed in control group of untreated samples $(0.85 \pm 0.27 \mathrm{MPa})$. Group I were significantly different $(p<0.05)$ from group II and group III.

Conclusion: Sandblasting with $30 \mu \mathrm{m}$ silica-coated aluminum oxide and $50 \mu \mathrm{m}$ aluminum oxide particles significantly increased the bond strength of acrylic surfaces.

\section{KEYWORDS}

PMMA, soft liner, surface properties, tensile bond strength

Denture soft liners have been applied in various positions for more than a century in prosthodontics. It is applied to the tissue surface of prosthesis. ${ }^{1}$ In 1945 , as a soft liner plasticized polyvinyl resin was developed. After than silicone-based materials were introduced in 1958. ${ }^{2}$ The function of soft lining material is shock absorption for the denture-bearing mucosa and to increasing retention of the prosthesis. $^{3}$ They are used for thin and atrophic mucosa, bony undercuts, irregular bony resorption, xerostomia, a risk for osteoradionecrosis,

\section{Öz}

Farklı yüzey modifikasyonlarının yumuşak astarın protez kaide materyaline bağlanması üzerine etkisi

Amaç: Çalışmanın amacı, polidimetilsiloksan protez astarını farklı boyutlardaki alüminyum oksit parçacıkları ile kumlanmış olan protez kaide maddesine gerilme bağlanma mukavemetini araştırmaktır

Gereç Yöntemler: Dikdörtgen prizma şeklinde kırk adet ısı ile polimerize edilmiş akrilik örnek bağlantı dayanımı için değerlendirilecektir. Örnekler uygulanan yüzey işlemine göre 4 test grubuna ayrılmıştır. Grup I: Yüzey işlemi uygulanmayan (kontrol grubu), Grup II: Kumlama ile birlikte tribokimyasal silika kaplama, Grup III: $50 \mu \mathrm{m}$ alüminyum oksit partikülleri ile kumlama, Grup IV: $110 \mu \mathrm{m}$ alüminyum oksit partikülleri ile kumlama. Bütün örnekler yumuşak astar ile bağlantı sağlandıktan sonra 5000 devir termal siklusa tabi tutulmuştur. Bağlantı değeri, evrensel test cihazı kullanılarak çekme test ile belirlenmiștir. Verilerin normalliği Shapiro-Wilk testi ile test edildi. Tüm veriler tek yönlü ANOVA kullanılarak analiz edildi ve ortalama değerleri Tukey'in HSD testi ile karşılaştırıldı. $(p<0.05)$

Bulgular: En yüksek bağ mukavemet değeri Grup II'de (1.51 \pm 0.41 $\mathrm{MPa}$ ) gözlendi. En düşük değer, yüzey işlemi uygulanmayan örneklerin bulunduğu grupta gözlendi $(0.85 \pm 0.27 \mathrm{MPa})$. Grup I, grup II ve grup III'den anlamlı olarak farklıydı $(p<0.05)$

Sonuç: Akrilik yüzeylerin $30 \mu \mathrm{m}$ silika kaplı alüminyum oksit ve 50 $\mu \mathrm{m}$ alüminyum oksit partikülleri ile kumlama işlemine tabi tutulması, bağlanma mukavemetini anlamlı olarak artırdı.

\section{ANAHTAR KELIMELER}

Polimetilmetakrilat, yumuşak astar, yüzey özellikleri, çekme dayanımı

parafunction, congenital oral defects requiring obturation, sensitivity in the mental foremen region, wrong occlusal relationship, bony spicules and implant placement surgery. ${ }^{4-9}$ In addition, soft liners provide distributed forces during function of tissue-supported prosthesis. Thereby, protection of the mucosa and patient comfort is provided. ${ }^{10}$ If soft lining materials are not used, tissues can be under the pressure by hard surface of polymethylmethacrylate (PMMA) and it may cause chronic soreness. ${ }^{4}$ Soft lining materials can be used at different time intervals from 6 months to 5

\footnotetext{
${ }^{*}$ This manuscript was submitted for oral presentation on 28-30 September 2017 at the 41. Annual Conference of European Prosthodontics Association, Bucharest, ROMANIA

${ }^{\alpha}$ Osmangazi University, Faculty of Dentistry, Department of Prosthodontics, Eskişehir, Turkey
} 
years. ${ }^{1}$ The properties of ideal soft lining material are easy application, acceptable bond strength with denture base, sustainable resilience and softness, no water absorption, nontoxic, non-allergic, easy cleaning, dimensional and color stability, repairable and resistance to forces. ${ }^{11}$

Soft liners can be classified in three groups: 1) According to the curing system (auto-cured, heatcured), 2) According to purpose of use (temporary, permanent), 3) According to their chemical structures (acrylic, vinyl, silicone). ${ }^{12}$

While auto polymerized soft liners enable the dentist to apply directly in the mouth, heat polymerized should be prepared in the laboratory. Auto-cured system is more acceptable than heat-cure system for patient. The reason of this first system is faster, cheaper and easier to apply than second system. Also patients don't have to wait for their prosthesis in this process. In contrary all of favorable properties, it is difficult to obtain sufficient thickness with a soft liner therefore it can easily undergo deformation and become infected. ${ }^{2,11}$

Soft liners based on acrylic usually contain powder and liquid. The structure of powder and liquid is composed of acrylic polymers and copolymers, along with a liquid containing an acrylic monomer and plasticizers (ethyl alcohol and/or ethyl acetate). It has been thought that the plasticizers in liquid are responsible for the primary softness. ${ }^{4}$ Silicone based soft liners and silicone dental impression materials are similar in terms of their contents. The both of them are essentially dimethylsiloxane polymers. Unlike acrylic, plasticizer is unnecessary for softness. ${ }^{4}$

Acrylic based soft liners provide better bonding to denture base due to their construction. Silicone soft lining material's bond strength to denture base is very low, so adhesives must be used to increase the bond strength. Water absorption of acrylic material is more than silicone. Surface of silicone lining material is more convenient for colonization of fungi and microorganism. Silicone based materials can keep their softness for longer time and that is more elastic than acrylic materials. The color stability of silicone lining material is better than acrylic resin materials. This may be explained with their higher hydrophobicity. ${ }^{11}$

Soft lining materials have many disadvantages besides their positive properties. Some of them have lost their softness over time, the growth of fungal and microorganism colonization, loss of dimensional stability, water absorption, porosity, low tear stress, color change and inadequate bonding force between the prosthetic base. ${ }^{8,11-14}$ Many studies have been conducted to investigate these problems. Several articles have been published on the prosthetic base to increase the bond strength. Examples of some surface treatments are alumina abrading, laser, oxygen plasma, glass fiber, nitric acid and argon plasma., ${ }^{3,510,15-17}$ Some failures can be observed depending on the time of bond strength between to denture base. They are caused by mechanical properties of denture base and reliner materials, aging of material, contacting with saliva and food, chewing forces, using of denture cleaners and temperature changes in mouth. ${ }^{18}$

In some of the studies, a thermocycling was applied to the specimens to stimulate the oral cavity. ${ }^{4,12,18}$ The use of thermal cycling in studies can increase or decrease the bond strength independently of the material ${ }^{1}$.

Peel, lap-shear and tensile test which are commonly used for evaluation of bonding characteristic of soft relining materials. Tensile test method was described to be effective by American Society for Testing and Materials (ASTM) for the evaluation useful of different adhesive systems and varied processing techniques. ${ }^{19}$

The aim of this in vitro study was to compare bond strength to denture base of silicone soft liner materials and define the effect of surface conditioning methods on the bond strength. The hypothesis tested was that the tensile bond strength obtained after sandblasting treatment of denture base resin is higher than any untreated group.

\section{MATERIALS AND METHODS}

Soft denture liner and denture base material used in this study are shown in the Table 1.

A steel mold was produced in order to obtain specimens in standard sizes (Figure 1). Forty pairs of heat-cured PMMA resin (Meliodent, Bayer Dental, Newbury, UK) specimens were prepared in the form of rectangle prism, according to the manufacturer's directions. Dimension of specimens is $10 \mathrm{~mm} \times 10 \mathrm{~mm}$ cross-sectional area and $30 \mathrm{~mm}$ length. The dies are divided by steel spacer with a thickness of $3 \mathrm{~mm}$ for soft lining application. Specimens were ground to a flat surface by hand grinding on wet 600 -grid silicone carbide paper. Then it was cleaned and dried. The steel spacer was removed from the mold, and the surface was prepared according to the manufacturers' directions.

The 40 pairs of specimens were divided to four groups.

Group I: This group was determined as the control group and no surface treatment was performed.

Group II: Acrylic base surfaces were sandblasted with $30 \mu \mathrm{m}$ silica-coated aluminum oxide particles $\left(\mathrm{Al}_{2} \mathrm{O}_{3}\right)$ (CoJet $^{\mathrm{TM}}$ Sand, 3M-ESPE, Seefeld, Germany) (Lot number 619274) for 10 seconds at a pressure of 2.8 bar, from a distance of $10 \mathrm{~mm}$ using an intraoral sandblaster. 
Group III: Acrylic base surfaces were sandblasted with $50 \mu \mathrm{m} \mathrm{Al}_{2} \mathrm{O}_{3}$ particles (3M ESPE, Seefeld, Germany) at a pressure of 2.8 bar 10 seconds $0.28 \mathrm{MPa}$ for 15 seconds from the tip of the air abration unit, equipped with a nozzle $5 \mathrm{~mm}$ in a diameter. (3M ESPE, Seefeld, Germany).

Group IV: Acrylic base surfaces were sandblasted with $110 \mu \mathrm{m} \mathrm{Al}_{2} \mathrm{O}_{3}$ particles (3M ESPE, Seefeld, Germany) at a pressure of 2.8 bar 10 seconds $0.28 \mathrm{MPa}$ for 15 seconds from the tip of the air abrasion unit, equipped with a nozzle $5 \mathrm{~mm}$ in a diameter. (3M ESPE, Seefeld, Germany).

The PMMA blocks were returned to the mold, and soft liners packed into the space made by the steel spacer, and heat polymerized according to the manufacturers' directions. After the polymerization, specimens were removed from the flask. All samples were thermocycled between 5 and $55^{\circ} \mathrm{C} 5000$ cycles to simulate oral environment.

Tensile bonding test were applied to the samples with universal testing machine (Lloyd LF Plus, Ametek Inc, Lloyd Instruments, Leicester, UK). Specimens were loaded until failure in a universal testing machine with a crosshead speed of $5 \mathrm{~mm} / \mathrm{min}$.
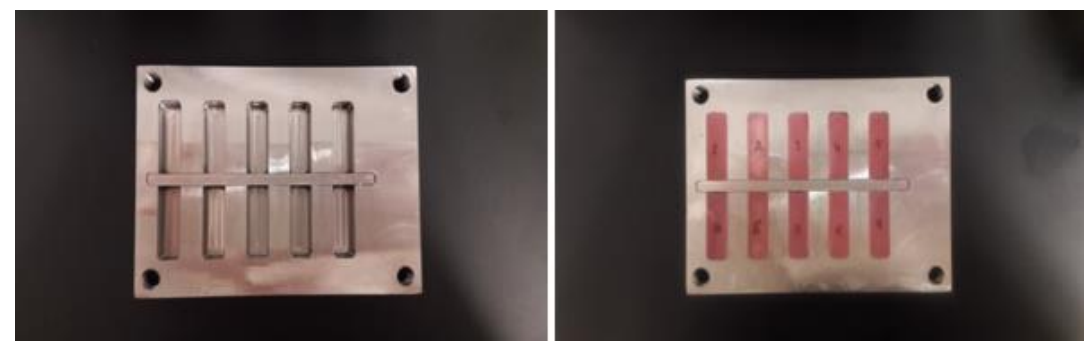

Figure 1.

The steel mold used in the work is seen in the figure

Table 1.

Materials used for the study

\begin{tabular}{|llll} 
Brand Name & Type & Manufacturer & Lot No \\
Molloplast-B & $\begin{array}{l}\text { Heatpolymerize, } \\
\text { silicone based, } \\
\text { definitive }\end{array}$ & Detax Dental & 190514 \\
Meliodent & $\begin{array}{l}\text { Heatpolymerize, } \\
\text { PMMA resin }\end{array}$ & $\begin{array}{l}\text { Heraeus Kulzer } \\
\text { GmbH Hanau }\end{array}$ & 13JUL145 \\
\hline
\end{tabular}

\section{Failure analysis}

By means of a stereomicroscope, debonded sample surfaces were evaluated by the same observer. (Stereomicroscope Leica M2 12, Leica Microsystems, Glattbrugg, Switzerland) Failure modes were assessed and classified as adhesive, cohesive or mixed type. Adhesive failure indicates a full separation at the interface between the soft denture liner and the prosthetic base material. Cohesive failure indicates rupture within the soft lining material. Mixed failure indicates a combination of cohesive and adhesive failures.

\section{Statistical Analysis}

Statistical analyzes were performed using the statistical software, statistical Package for the Social Sciences, version 22 for Windows (SPSS Inc., Chicago, IL, USA).

Tensile bond strengths of the tested groups were evaluated by one-way ANOVA. The Shapiro-Wilk test was performed to confirm that the data of tensile bond strength values were normally distributed. Statistical analyses were performed at a significance level of 0.05 . Multiple comparisons of different surface treatments were undertaken using the Tukey-HSD test.

\section{RESULTS}

Table 2 summarizes the mean values and standard deviations of tensile bond strength data for all groups. Among the groups tested the highest mean tensile bond strength was observed in the groups II (1.51 \pm 0.41 $\mathrm{MPa})$. The lowest mean tensile bond strength value was observed for the group I (0.85 $\pm 0.08 \mathrm{MPa})$. Tukey's HSD test showed that the tensile bond strengths in group I was significantly different from group II and group III. $(p<0.05)$ There was no significant difference in bond strength between groups group I and group IV. Furthermore, no significant difference was found between group II, group III and group IV.

In addition, failure types are presented in Table 3. Group III and IV samples presented $100 \%$ adhesive failure. Additionally, Group I samples predominated in adhesive failure (80\%). However, Group II samples presented $60 \%$ mix, 30\% adhesive, 10 $\%$ cohesive failure. 
Table 2.

One- way Anova results for Mean and standard deviation of
tensile bond strength values (MPa)

\begin{tabular}{|cccccccccc} 
& N & Mean & Minimum & Maximum & $\begin{array}{c}\text { Standart } \\
\text { Deviation }\end{array}$ & $\begin{array}{c}\text { Standart } \\
\text { Eror }\end{array}$ & \multicolumn{2}{c}{$\begin{array}{c}\text { \%95 Confidence Interval } \\
\text { for Mean }\end{array}$} \\
\hline Group I & 10 & $0.85^{\mathrm{a}}$ & 0.56 & 1.34 & 0.27 & 0.08 & 0.66 & 1.05 \\
\hline $\begin{array}{c}\text { Group } \\
\text { II }\end{array}$ & 10 & $1.51^{\mathrm{b}}$ & 1.04 & 2.41 & 0.41 & 0.13 & 1.21 & 1.81 \\
\hline $\begin{array}{c}\text { Group } \\
\text { III }\end{array}$ & 10 & $1.33^{\mathrm{b}}$ & 0.52 & 1.87 & 0.40 & 0.12 & 1.04 & 1.62 \\
\hline $\begin{array}{c}\text { Group } \\
\text { IV }\end{array}$ & 10 & $1.21^{\text {ab }}$ & 0.72 & 1.78 & 0.34 & 0.11 & 0.96 & 1.46 \\
\hline
\end{tabular}

Groups with the same superscript letter are not significantly different $(p>0.05)$
Table 3.

Failure types and numbers
$(n=10)$

\begin{tabular}{|c|c|c|c|}
\hline \multirow{2}{*}{ Group } & \multicolumn{3}{|c|}{ Type of failure } \\
\hline & Cohesive & Adhesive & Mix \\
\hline Group I & & 8 & 2 \\
\hline Group II & 1 & 3 & 6 \\
\hline Group III & & 10 & \\
\hline Group IV & & 10 & \\
\hline
\end{tabular}

\section{DISCUSSION}

The result obtained in the present study show that application of sand blasting to the denture base material increases the bond strength between soft liner and denture base material, thus the first hypothesis was accepted. Clinically, bonding properties of prosthetic lining materials is important under chewing stress. Optimally, soft lining materials should be strongly bonded to the acrylic resin during the lifetime of the prosthesis to prevent separation from the base material. In the current study, to increase the bond strength of the soft denture liner to the denture base materials, different surface modification methods were applied, such as sandblasting with different particle size.

After the tensile strength test, different types of failures were observed among the groups on failure. Failure analysis results showed that group II which was sandblasted with $30 \mu \mathrm{m}$ silica-coated aluminum oxide particles had the highest bond strength and 30\% adhesive failure, $60 \%$ mixed failure and $10 \%$ cohesive failure. On the other hand, group I (control group) showed the lowest bond strength with $80 \%$ adhesive failures and $20 \%$ mix failure.

Laboratory experiments, with the soft lining of the bonding forces denture base materials was carried out using different methods of testing by various researchers, for example shear, tensile or peel tests. ${ }^{20-}$ ${ }^{26}$ The tensile bond strength test has been extensively used by researchers. In this study, the tensile test method is preferred because it provides the surface of the draft; it can give information about the structure of the boundary layers and the location of the failures..$^{21,27,28}$ Although it is believed that the peel test is the best simulation test for soft lining materials for clinical lining materials, the results indicated that the peel tests are likely to cause higher cohesion failures in soft denture lining materials and this test may be affected by the material thickness. Shear adhesion strength of the material is also influenced by the deformation rate. In the tensile bond test, the coated area is stretched simultaneously and is not allowed for deformation of materials. Although the tensile test does not mimic the clinically exposed forces of the lining material, it is well-considered a suitable method. ${ }^{12,19,28}$ Also soft denture liners did not cause tensile stresses by pulling forces alone, such as some shear forces due to the high Poisson's ratio. As well as for soft lining materials to be acceptable for clinical use; have been reported to have a bond strength of at least $0.44 \mathrm{MPa}\left(4.5 \mathrm{~kg} / \mathrm{cm}^{2}\right) .{ }^{27} \mathrm{In}$ general, we estimate that the prosthesis can be changed on average every 5 years. Acceptable softlined prostheses should also provide this life period. Bond strength between the soft liner and the acrylic resin must be sufficient for to prevent soft liner separating from denture base. As a result of this separation unhygienic and non-functional area may become. $^{2}$

Thermal cycling is a widespread method for imitating more closely the oral condition. This process causes repeated enlargement and contraction between the soft denture liners and the prosthetic base material, while at the same time causing stress and thermal volumetric changes in the bonding interface. It has been determined that thermal cycling stress is one of the disruptive factors among the soft denture liners and denture base resins. Just as in previous studies, in this research the thermal cycling was done only to simulate the oral environment. For this reason, the bonding forces were not compared before and after the thermal cycling. In this study, 5000 thermal cycles were chosen. The temperature changes from $5^{\circ} \mathrm{C}$ to $55^{\circ} \mathrm{C}$ in the thermal cycling procedure. 5000 thermal 
cycles simulate the use of total prostheses in about 5 years for a patient thought to eat three meals a day. ${ }^{1,12,29,30}$

It is accepted that soft lining material develops adhesion strength to the prosthetic base by producing air-borne particle abrasion of acrylic resin, which will facilitate mechanical interlocking. However, the results of the investigations should be discussed. Gundogdu et $\mathrm{al}^{13}$ and Akın et $\mathrm{al}^{15}$ reported that abrasion of the acrylic resin with $50-\mu \mathrm{m}$ alumina particles resulted in lower bond strength compared to the control samples with airborne particle abrasion. Atsu and Keskin ${ }^{12}$ discovered that airborne abrasion with $50 \mu \mathrm{m}$ alumina and $30 \mu \mathrm{m}$ silica coated alumina oxide particles did not increase the adhesive strength of the flexible lining material to the prosthetic base resin. It has been suggested that the debilitating effect of airborne abrasion on the bond strength may result from stresses produced at the interface of the acrylic resin-resistant liner or due to the insufficient size of irregularities caused by airborne abrasion to penetrate the material itself however, some researchers indicated that airborne particle abrasion of the acrylic resin prosthesis surface improves the binding force of soft denture lining materials ${ }^{31}$. In addition, Usumez et $\mathrm{al}^{5}$ reported that airborne particle abrasion of $250 \mu \mathrm{m}$ aluminum oxide particles to acrylic resin resulted in higher bond strength compared to the control group, but this increase was not statistically significant. ${ }^{5}$ All groups airborne based on the results of this study showed high bond strength than the control group. Sandblasted with $50 \mu \mathrm{m}$ aluminum oxide particles and $30 \mu \mathrm{m}$ silica-coated aluminum oxide particles exhibited higher bond strength at statistically significant level. There was no statistically significant difference between $110 \mu \mathrm{m}$ aluminum oxide particles and control group. Because the $110 \mu \mathrm{m}$ diameter forms larger retention focus on the acrylic surface, the bonding areas may be insufficient compared to $30 \mu \mathrm{m}$ and $50 \mu \mathrm{m}$ sandblasting.

There is no plasticizer in content of Molloplast-B, it does contain filler. The filler may cause to increase softness, because of it absorbate water. Due to these reasons, Molloplast- $B$ is affected thermocycling. ${ }^{4}$ It is possible to find many studies which comparing acrylic and silicone soft liner in the literature. El-Hadary et al reported that silicone based soft lining material's bond strength to denture base is stronger than acrylic based soft liner. ${ }^{32}$ On the contrary, Mutluay and Ruyter founded silicone based soft denture liner's bond strength is lowest. ${ }^{19}$ Aydın et al reported although acrylic was higher bond strength than silicone at the beginning of the study after the thermocycling silicone based material's bond strength to denture base was founded the highest. ${ }^{33}$
This research is an in vitro study. The thermocycling isn't sufficient to simulate the mouth environment. There are many variables in the mouth such as saliva, chewing force, microorganism and foods. Therefore, long-term clinical studies are required to obtain more accurate results.

\section{CONCLUSION}

Within the limitation of this research, under the present experimental conditions, the following conclusions can be drawn:

Different size of aluminum oxide particles was effect the bond strength of the silicone based soft denture liner to the heat cured based resin.

The highest tensile bond strength between the denture base resin and the silicone based soft denture liner was obtained by application of sandblasting with $30 \mu \mathrm{m}$ silica-coated aluminum oxide particles. In addition, there was no statistically significant difference between the other sandblasting parameters. The adhesive failure type was predominantly observed. 


\section{REFERENCES}

1. Hatamleh MM, Maryan CJ, Silikas N, Watts DC. Effect of net fiber reinforcement surface treatment on soft denture liner retention and longevity. J Prosthodont. 2010; 19(4): 258-62.

2. Meşe A, Güzel KG, Uysal E. Effect of storage duration on tensile bond strength of acrylic or silicone-based soft denture liners to a processed denture base polymer. Acta Odontol Scand. 2005; 63(1): 31-5.

3. Zhang H, Fang J, Hu Z, Ma J, Han Y, Bian J. Effect of oxygen plasma treatment on the bonding of a soft liner to an acrylic resin denture material. Dent Mater J. 2010; 29(3): 398-402.

4. Ribeiro Pinto JR, Ferraz Mesquita M, Pessanha Henriques GE, De Arruda Nóbilo MA. Effect of thermocycling on bond strength and elasticity of 4 long-term soft denture liners. J Prosthet Dent. 2002; 88(5): 516-21.

5. Usumez A, Inan O, Aykent F. Bond strength of a silicone lining material to alumina-abraded and lased denture resin. J Biomed Mater Res - Part B Appl Biomater. 2004; 71(1): 196-200.

6. Wady AF, Machado AL, Zucolotto V, Zamperini CA, Berni E, Vergani CE. Evaluation of Candida albicans adhesion and biofilm formation on a denture base acrylic resin containing silver nanoparticles. J Appl Microbiol. 2012; 112(6): 1163-72.

7. Akay C, Çevik P, Duman AN. Farklı içeceklerde bekletilen yumuşak astar materyalleriinin renk stabilitesīnin învitro olarak değerlendïrilmesï. Atatürk Üniversitesi Diş Hekimliği Fakültesi Dergisi. 2016; 26(2).

8. Lima MA De, Miranda ME, Turssi CP, Pereira EC, Renato J, Pinto R, et al. Effect of antifungal agent on bond strength of one long-t erm soft denture liner. 2016; 9(1)

9. Akay $\mathrm{C}$, Tanış $\mathrm{M}$, Sevim $\mathrm{H}$. Effect of artificial saliva with different ph levels on the cytotoxicity of soft denture lining materials. Vol. 40, International Journal of Artificial Organs. 2017. p. 581-8.

10. Lassila LVJ, Mutluay MM, Tezvergil-Mutluay A, Vallittu PK. Bond Strength of Soft Liners to FiberReinforced Denture-Base Resin. J Prosthodont. 2010; 19(8): 620-4.

11.Bal BT, Yavuzyılmaz H. Yumuşak astar maddeleri. Atatürk Üniversitesi Diş Hekim Fakültesi Derg. 2006; 53-60.

12. Atsu S, Keskln Y. Effect of silica coating and silane surface treatment on the bond strength of soft denture liner to denture base material. J Appl Oral Sci. 2013; 21(4): 300-6.

13.Gundogdu M, Yesil Duymus Z, Alkurt M. Effect of surface treatments on the bond strength of soft denture lining materials to an acrylic resin denture base. J Prosthet Dent. 2014; 112(4): 964-71.
14.Usta Kutlu I, Yanikoğlu ND, Kul E, Duymuş ZY, Sağsöz NP. Effect of sealer coating and storage methods on the surface roughness of soft liners. J Prosthet Dent. 2016; 115(3): 371-6.

15.Akin H, Tugut F, Mutaf B, Akin G, Ozdemir AK. Effect of different surface treatments on tensile bond strength of silicone-based soft denture liner. Lasers Med Sci. 2011; 26(6): 783-8.

16. Atat DF, Cilt U, Duman A, Kodu M, Tarihi K. Astarlama öncesi akrilik rezin yüzeyine ultraviyole işinlama ve nitrik asit uygulamanin kaide rezini ve yumuşak astar materyallerde oluşturduğu kimyasal değişikliklerin değerlendirilmesi. 2016; 261-7.

17. Yildirim Bicer AZ, Dogan A, Keskin S, Dogan OM. Effect of argon plasma pretreatment on tensile bond strength of a silicone soft liner to denture base polymers. J Adhes. 2013; 89(7): 594-610.

18. Goiato MC, Medeiros RA De, Estadual U, Bonifacio RJ, Mendonca V, Division DM. Tensile bond strength of a soft liner to an acrylic resin after primer application and thermocycling. 2015; 18(6): 1183-7.

19. Mutluay MM, Ruyter IE. Evaluation of bond strength of soft relining materials to denture base polymers. Dent Mater. 2007; 23(11): 1373-81.

20.Tugut F, Coskun ME, Dogan DO, Kirmali O, Akin $\mathrm{H}$. Tensile Bond Strength between Soft Liners and Two Chemically Different Denture Base Materials: Effect of Thermocycling. J Prosthodont. 2016; 25(4): 319-23.

21.Akin $H$, Tugut $F$, Mutaf $B$, Guney U. Investigation of bonding properties of denture bases to silicone-based soft denture liner immersed in isobutyl methacrylate and 2-hydroxyethyl methacrylate. J Adv Prosthodont. 2014; 6(2): 121.

22. Kim BJ, Yang HS, Chun MG, Park YJ. Shore hardness and tensile bond strength of long-term soft denture lining materials. J Prosthet Dent. 2014; 112(5): 1289-97.

23. Sánchez-Aliaga A, Pellissari CVG, Arrais CAG, Michél MD, Neppelenbroek KH, Urban VM. Peel bond strength of soft lining materials with antifungal to a denture base acrylic resin. Dent Mater J. 2016; 35(2): 194-203.

24.Rajaganesh N, Sabarinathan S, Azhagarasan NS, Shankar C, Swathi S. strength of two different chairside soft liners. 2016; 154-60.

25.Ekren O, Ozkomur A. Influence of ozone and paracetic acid disinfection on adhesion of resilient liners to acrylic resin. J Adv Prosthodont. 2016; 8(4): 290. 
26. Demir H, Dogan A, Dogan OM, Keskin S, Bolayir G, Soygun K. Peel bond strength of two silicone soft liners to a heat-cured denture base resin. J Adhes Dent 2011; 13(6): 579-84.

27. Kulkarni RS, Parkhedkar R. The effect of denture base surface pretreatments on bond strengths of two long term resilient liners. J Adv Prosthodont. 2011; 3(1): 16.

28.Demir H, Soygun K, Dogan A, Keskin S, Dogan OM, Bolayir G. Effect of maleic anhydride pretreatment on tensile bond strength of a silicone soft liner to a denture base polymer. J Adhes Dent. 2011; 13(5): 481-7.

29. Atsü SS, Gelgör IE, Sahin V. Effects of silica coating and silane surface conditioning on the bond strength of metal and ceramic brackets to enamel. Angle Orthod. 2006; 76(5): 857-62.

30.Torres León BL, Del Bel Cury AA, Rodrigues Garcia RCM. Water sorption, solubility, and tensile bond strength of resilient denture lining materials polymerized by different methods after thermal cycling. J Prosthet Dent. 2005; 93(3): 282-7.

31. Nakhaei M, Dashti H, Ahrari F, Vasigh S, Mushtaq $S$, Shetty RM. Effect of different surface treatments and thermocycling on bond strength of a siliconebased denture liner to a denture base resin. $J$ Contemp Dent Pract. 2016; 17(2): 154-9.

32. El-Hadary A, Drummond JL. Comparative study of water sorption, solubility, and tensile bond strength of two soft lining materials. J Prosthet Dent. 2000; 83(3): 356-61.

33.Aydın A., Terzioğlu H, Akınay A., Ulubayram K, Hasırc $\mathrm{N}$. Bond strength and failure analysis of lining materials to denture resin. Dent Mater. 1999; 15(3): 211-8.

Corresponding Author:

Canan AKAY

Osmangazi University

Faculty of Dentistry

Department of Prosthodontics

Eskişehir, Turkey

Phone : +90 5303338626

E-mail :cnngcr2@hotmail.com 